\title{
Visual Monitoring as a Tool in Industrial Security Engineering. Case Study
}

doi:10.2478/mape-2021-0010

Date of submission to the Editor: $04 / 2021$

Date of acceptance by the Editor: 06/2021

MAPE 2021, volume 4, issue 1, pp. 107-119

Jolanta Ignac-Nowicka

ORCID ID: 0000-0002-8164-6326

Silesian University of Technology, Poland

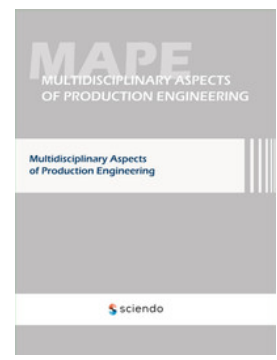

\section{INTRODUCTION}

Currently, high demands are placed on the industrial activity of man, especially in terms of shaping the interaction of industrial enterprises with the environment. Companies are required to:

- minimize actions that threaten the safety of employees and the environment in which the society lives,

- accepting responsibility for damage caused by accidents at work and environmental pollution,

- integrating quality, ergonomics, safety and environmental protection into the goals, mission and strategy of the company (Gembalska-Kwiecień, 2018).

For this purpose, various techniques and tools of strategic and operational controlling are used (Konsek-Ciechońska, 2017). Safety engineering is of great importance in production and maintenance in the chemical, mining, machinery, energy, transport and other industries, safety engineering is of great importance and covers all areas of technology. Technical safety engineering and work safety engineering play a major role in monitoring safety in the area of industrial plant operations. One of the tools of technical safety engineering is CCTV along with numerous security surveillance functions in the enterprise (Ignac-Nowicka, 2018a, Lim et al., 2014, Nguyena et al., 2020).

\section{VISUAL MONITORING AS A TOOL IN SECURITY ENGINEERING}

In industrial plants, video surveillance is becoming a standard and commonly used practice in securing property, especially against vandalism, theft or third party intrusion into the company's premises (Żabicki, 2013). Video monitoring in a company can play an important role in previewing a selected part of the technological process or control the behavior of employees by registering, for example: avoidance of health and safety regulations. Video monitoring by recording emerging threats allows you to obtain important information related to the safety level in any space of an industrial plant. 
Due to the nature of the work of vision systems in buildings and in the open space, three main functions of the CCTV system can be distinguished: preventive, operator and evidence. The preventive function consists in informing about the installed video monitoring to discipline the behavior of people who must take into account the possibility of registering their image and identification. The operator function is based on the reaction of the monitoring operator, who tracks the images from cameras in real time and reacts to threats visible on the screen. This function is often used in the monitoring of industrial processes and the safety of workplaces. On the other hand, the evidentiary function consists in recording the image from cameras on a suitable medium in order to obtain the possibility of recreating the events also after some time. This function is particularly useful in determining the course of events after an accident at work. Video monitoring systems are therefore an important preventive and protection measure, which enables viewing places and objects from a distance (IgnacNowicka, 2018a, Ignac-Nowicka, 2016).

Until recently, the closed-circuit television system was considered a separate system and closed, currently vision systems cooperate with many different security systems, providing current and valuable information on the credibility of the occurring alarm phenomena as various types of threats signaled by other warning systems.

\section{Basic concepts related to video surveillance}

In the literature on the subject, you can find many definitions and terms relating to video monitoring. One of them states that "video monitoring" is an information transmission system consisting in planned (continuous, strictly defined, using a procedure and functional guidelines) observing (often also recording), by technical means, events, that occur in specific place. This monitoring is aimed at preventing crimes, offenses, accidents and assigning blame and responsibility for committed acts (Ordysińska, 2006). Another definition specifies that the concept of "video monitoring, also known as closed-circuit television (CCTV) - is a definition of a system for transmitting and recording images from specific places in a closed receiving system, aimed at supervising the area where the cameras of this system have been installed" (Kister, 2010). According to P. Kałużny, "television surveillance systems - are sets of technical and programming means intended for the observation, detection, recording and signaling of conditions indicating the existence of a risk of damage or threats to people and property (Kałużny, 2008). It should also be mentioned the definition of video monitoring proposed by the Inspector General for Personal Data Protection in the requirements for monitoring regulation, according to which: "monitoring (video surveillance) - is the remote reception of an image or image and sound from the space located in the field of view of cameras installed in specific points near the monitored area". On the other hand, monitoring system

- is a set of cameras, transmission devices, electronic data carriers, data 
recording devices, devices reproducing recorded data and software used to achieve specific monitoring functionality.

\section{Construction of vision systems}

In order for the video monitoring to fulfill its basic functions, the closed-circuit television system should be equipped with appropriate devices. A vision system usually consists of the following devices:

- cameras - devices for observing and processing the image into an electrical signal,

- monitors - devices used to convert the signal from cameras into the displayed image,

- video signal transmitting devices,

- devices controlling utility functions (image changers and image dividers quads, multiplexers, matrix switchers, control keyboards),

- archiving devices (time-lapse video recorders, computer discs for digital recording) (Ignac-Nowicka, 2018a).

The cameras will enable observation of protected areas. In vision systems, cameras with black-and-white and color images are used, depending on the type of desired information that should be displayed on the monitor and/or stored on an appropriate information carrier. Each camera consists of: a CCD converter, a lens and a set of electronic devices that process the electrical signal. The suitability of cameras for use in specific applications is determined by their basic parameters, such as:

- sensitivity (related to the level of illumination of the observed scene in lux),

- resolution,

- viewing angles - the size of the observed area in stationary cameras (Wójcik, 2004, Elhanrrouss et al., 2021).

The vision system monitors should work properly in an environment with a relative humidity of up to $90 \%$ and in the temperature range from 0 to $40^{\circ} \mathrm{C}$, and the resolution should be over 400 lines for color monitors and 1000 lines for black and white monitors. Monitors with a screen of different sizes are used. When using large monitors and image dividers, do not exceed 10 images from cameras on one monitor, because the greater number causes the employee's distraction and prevents the correct response to emerging events, especially in emergency situations (Donald et al., 2015).

Multiplexers are devices that simultaneously perform the actions of an image changer and an image divider. The multiplexer enables simultaneous operation of many cameras and at the same time enables displaying high quality fullscreen images on a separate screen. The quality of the displayed image on the monitor is determined by the resolution of the multiplexer (Wójcik, 2004, Elharrouss et al., 2021).

Video matrixes are devices that transmit the video signal from cameras to monitors or multiplexers. They make it possible to organize cable connections 
for a large number of signals. Thanks to the use of patch panels, the network architecture of the vision system can be easily managed. The functions of the matrixes are programmable and allow for free directing of the image to the monitor or to the recording devices, enabling the creation of any network architecture of the video system (Wójcik, 2004).

Image recording on recording devices can be performed in an analog or digital manner. For analog recording, time-lapse video recorders are used (they record only selected frames), which enable the recording of long video observation times. Digital recording on computer disks gives greater possibilities of analyzing the observed image and recording only the image during its change, omitting constant phenomena in the environment, e.g. sunrise, etc. In addition, the digital image can be sent to any place, if the CCTV system is connected to the network website. An important element of closed-circuit television is also a keyboard controlling the entire CCTV system, usually with a built-in joystick for manipulating PTZ cameras (cameras with the ability to rotate and zoom) (PNEN 62676-4, 2015).

In the era of digitization, the technology of image transmission and its recording itself has also changed. Analog monitoring systems have been replaced by more advanced digital technology, which creates much greater possibilities of its direct application in various industrial plants. This is due to the improvement of image quality, increased resistance to interference and the possibility of building multiple distributed digital video monitoring systems. IP monitoring systems based on Ethernet networks are becoming more and more popular. Their transmission signals contain images from cameras, which are then sent via local or global computer networks. This enables the creation of an uncomplicated system infrastructure that connects cameras with surveillance points of video monitoring operators anywhere (PN-EN 62676-4, 2015).

\section{Advantages of vision systems in industrial environments}

The advantages of monitoring systems in industrial plants are twofold. On the one hand, you gain supervision over the technical infrastructure, and on the other, broadly understood protection of property and employees. With regard to the technical aspect, it is important to supervise the safety of industrial processes and the safety of industrial machines. Having a continuous overview of the machine, you gain the possibility of early detection of a defect, and thus preventing unplanned stoppages of machines (Pihowicz, 2005). Monitored machine safety in an industrial plant brings financial benefits. In this way, the expenses incurred for the machine monitoring system should be treated as an investment.

The benefits of the monitoring system can also be considered in terms of supervision over compliance with occupational health and safety regulations. Control and the ability to enforce the requirements of safe and hygienic work of own employees and external companies allows to reduce the number of accidents caused by the so-called the human factor (Gembalska-Kwiecień, 
2018). In addition, the monitoring system is a good way to discipline employees and has a preventive function.

In terms of property protection, the most important advantages of monitoring in industrial plants include: the possibility of supervising the area, the interior of buildings, production halls as well as industrial infrastructure devices and machines. As a result, CCTV systems are used in industrial plants, regardless of their size, in closed and open spaces (Pihowicz, 2008, Donald el al., 2015).

\section{INTRODUCTION OF VIDEO MONITORING TO THE SUPERVISION OF SELECTED HEAT PRODUCTION PROCESSES. CASE STUDY}

A municipal thermal power plant was selected for research analyzes, the main pillar of which is the production, transmission and distribution of district heat. The selected heating plant in the city provides thermal energy: industrial facilities, public utility facilities such as cinemas, museums, administrative buildings, offices, schools, residential buildings, etc.

There is an entrance gate with a truck scale and a scale service building leading to the plant. The control and identification of people and vehicles crossing the factory gate is supervised by a security guard who is permanently present in the building with truck scales. The duties of the security officer also include supervision over the premises of the entire plant. The boiler house building covers approximately $500 \mathrm{~m}^{2}$ of land, around which there are car parks, roads for pedestrians and internal communication routes.

The area also includes a roofed landfill of fine coal supplied to the heating plant from outside. Near the coal storage yard, a belt conveyor with a charging grate is installed, whose task is to transport fine coal to the boiler house. There is also a shelter with heavy equipment, which includes a backhoe loader, a wheel loader and a crawler dozer. These machines are supplied with fuel from a distributor located next to the shelters.

\section{Characteristics of the heat production process in the selected enterprise}

The carrier of thermal energy produced in the heating plant is water, which is used for central heating of buildings and as domestic hot water. Thermal energy is generated by burning hard coal, which is delivered to the plant by road.

The boiler house building of the analyzed municipal thermal power plant has 4 levels (storeys). The deslagging process is carried out at level 0 of the boiler house. At this level of the hall, one of the coal dust combustion products, ie slag, is discharged outside, by means of a belt conveyor. In addition, on level 0 there is a coal sample laboratory, a spare parts warehouse, a mechanical and electrical workshop and a part of the hall located under the boilers.

Level 1 is the level of the boiler hall, containing the control room, the room of the boiler room master, the contactor room with control cabinets for the heat generation process, as well as a social room and a cloakroom for employees. In the boiler hall, heat is generated for the city by burning fine coal in two boilers with a total power of $9 \mathrm{MW}$. The entire technological process of the plant is 
supervised by the heating plant dispatcher who is in the control room and other employees at various positions who are in constant contact with him.

On level 2 there is a utility room and water softening is carried out to give it appropriate parameters. It is a heat carrier for customers in the city. Level 3 of the boiler house is the carburizing level located on the top floor of the building. At this level, the belt conveyor ends, which transports coal dust from the coal storage yard to the tanks of individual boilers. The selection of the charging tank is made by the heat station dispatcher, while the employee of the carburizing department places the conveyor belt over the appropriate tank. A scale is installed on the conveyor belt to control the consumption of fine coal.

\section{Analysis of threats in a selected enterprise}

The risk analysis carried out in the selected municipal thermal power plant concerned the stages of heat production, such as: the process of supplying energy raw material to the plant, internal transport, raw material combustion, heat distribution and the maintenance process of machines. The following threats or significant difficulties in the work process have been identified:

- in the area of the main gate, there is no visibility of pedestrians and vehicles standing in front of the gate awaiting the opening of the barrier,

- in the process of weighing transport sets entering with a load, no visibility of the vehicle registration numbers (the scale operator is each time forced to leave the weighing room in order to read the vehicle registration numbers in accordance with the procedure),

- lack of visibility of the correct position of the vehicle wheels on the scale in the process of weighing empty vehicles after unloading,

- no control of pedestrian traffic associated with the entrance to the boiler house (main and rear entrances),

- no supervision of the coal storage area (no fire safety control) and no supervision of machines during the transport of fine coal,

- no control of the stoppage of heavy equipment (e.g. wheel loader, crawler dozer and backhoe loader) - as a result, there is no tool allowing to record the working time of machines,

- no control of the fuel dispenser operation - as a result, no supervision over the process of refueling heavy equipment in terms of health and safety and fire protection,

- lack of supervision over the process of backfilling the carburizing grate in the process of filling the boilers of the heating plant - the possibility of clogging of the carburizing grate, as a result, there is a problem of blocking or sudden unblocking of the material on the carburizing grate, which affects uneven loading of the conveyor and exceeding its operating parameters,

- no control of the vehicle position under the discharge hopper at the slag loading site, 
- lack of control of workstations in the repair shop, where non-compliance with health and safety rules was noted, resulting in accidents at work,

- lack of constant control of the boiler hall, which results in the lack of control of boiler leaks, water leaks and failure of electrical machines,

- no constant overview of the various stages of firing up and extinguishing the furnace of the boiler and controlling the operation of the furnace in the event of a failure of the control and visualization system,

- lack of control over the violation of the ban on the use of open fire and smoking by employees in the designated explosion zone containing coal dust.

The FTA and ETA methods were used to identify threats in the surveyed company (Ignac-Nowicka, 2018b). Some of the above-mentioned risks have a direct impact on work safety, while the remaining ones have a significant impact on labor costs and difficulties in the work process. In order to increase the level of safety and efficiency in the work process, the above-mentioned areas were analyzed and the use of video surveillance was proposed.

\section{Selection of surveillance areas with vision systems}

Due to the occurrence of hazards and difficulties in work in the municipal thermal power plant, a video monitoring system was used to supervise the areas that were analyzed. It is planned to place 16 cameras (10 cameras in the outer part of the heating plant and 6 cameras inside the building). When locating the cameras outdoors, it is necessary to take into account the effects of external weather conditions (precipitation, wind, extremely low and high temperatures, dust) as well as the risk of theft and sabotage attempts.

The video monitoring system introduced on the premises of the plant is intended to separate the rights related to the access to the image from the cameras. The preview of the image from the cameras was divided between the security service located in the weighing room at the main gate, and the heat plant dispatcher, who is responsible for the technological part of the plant's operation and the safety of the works performed. In principle, the image from cameras no. 1-8 is available for the security service, while the heat plant dispatcher in the control room has the ability to view the image from all cameras. Cameras no. 9-16 serve, inter alia, as a preview of the technological process, so access to them is provided only to the dispatcher of the heating plant. The arrangement of cameras monitoring the external area of the heating plant is shown in Figure 1. There are 10 external cameras in the external area of the heat plant. The location of the camera no. 1 is planned in the area of the entrance gate, and the cameras no. 2 and 3 , depending on the direction of the weighed vehicle, will cover the entrance to or exit from the weighbridge. The mounting height of the cameras results from the necessity to ensure the visibility of the truck's registration number. Cameras no. 4 and 5, which cover the main entrance to the boiler house building, control passenger traffic (employees and guests). 


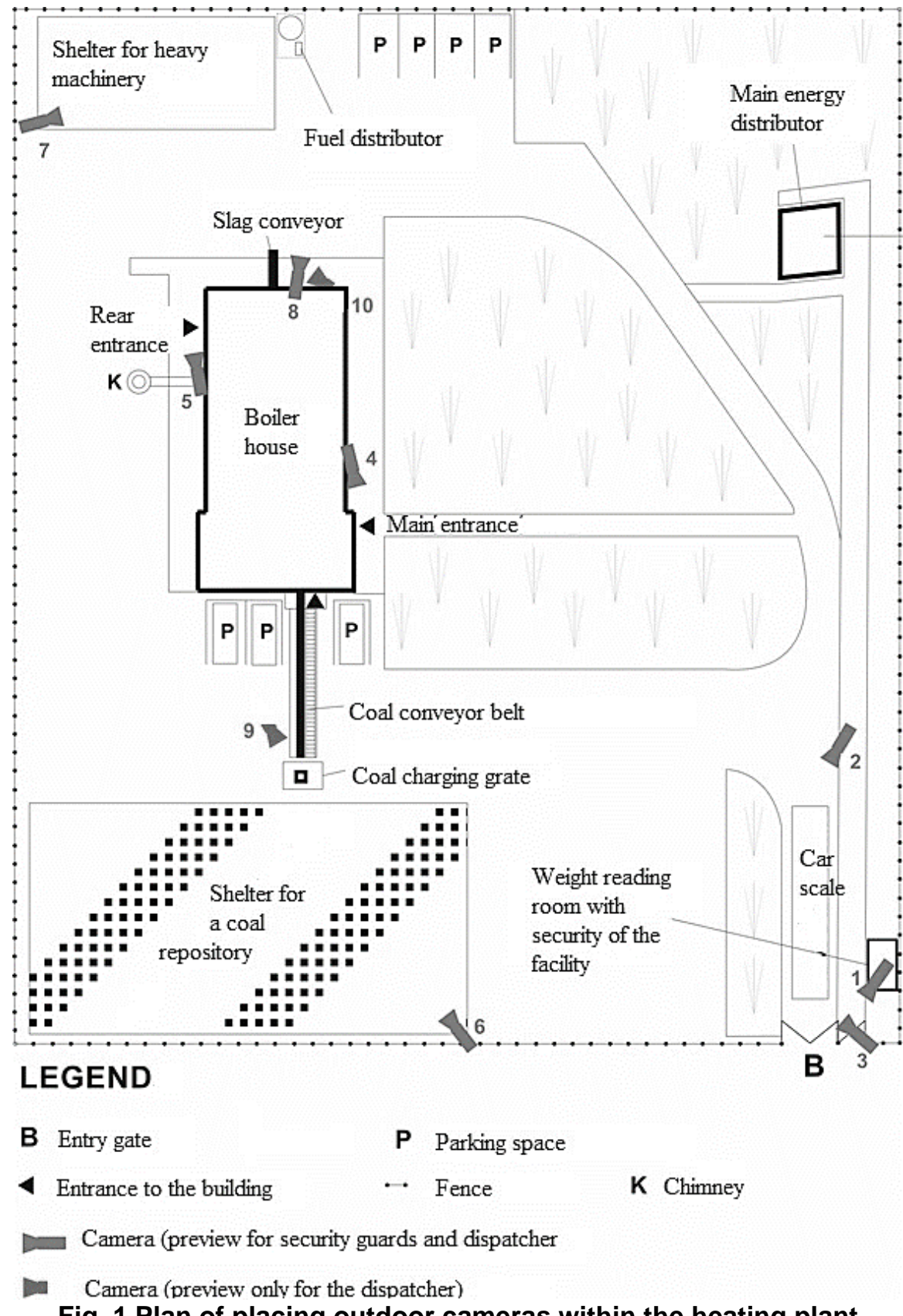

Source: own study

Fig. 1 Plan of placing outdoor cameras within the heating plant

Any movement of unauthorized persons should be intercepted by security services or the heat plant's dispatcher. Camera no. 6 covers the shelter of the coal storage facility. Monitoring of this area results from the need to observe the equipment during the carburizing process and the movement of delivery vehicles, as well as fire safety.

Camera no. 7 monitors the shelter with heavy equipment in order to protect property and the need to record the working time of machines. Camera no. 8 mounted on the building wall will cover the fuel dispenser and the car park, supervising the refueling process of heavy equipment in terms of compliance with refueling instructions and fire safety. In addition, supervision covers the unloading of fuel to the ground tank next to the dispenser. The next camera no. 
9 will cover the carburizing grating. Video surveillance of this place allows you to monitor the operation of heavy equipment during the carburizing process and control of the chute patency. It is important to observe this place from the point of view of the safety of people who pour coal. Monitoring of the deslagging conveyor by the camera no. 10 allows the observation of the slag loading site and the correctness of the vehicle positioning under the discharge hopper. In addition, the view on the conveyor allows you to determine the absence of random people who may appear while maneuvering and loading the vehicle. At the deslagging level, camera no. 11 is provided with a view of the workshop, where mechanical works such as cutting, grinding, drilling and welding may pose a significant risk of accidents at work.

Figure 2 shows the location of the vision system cameras for exemplary levels of the boiler house building.
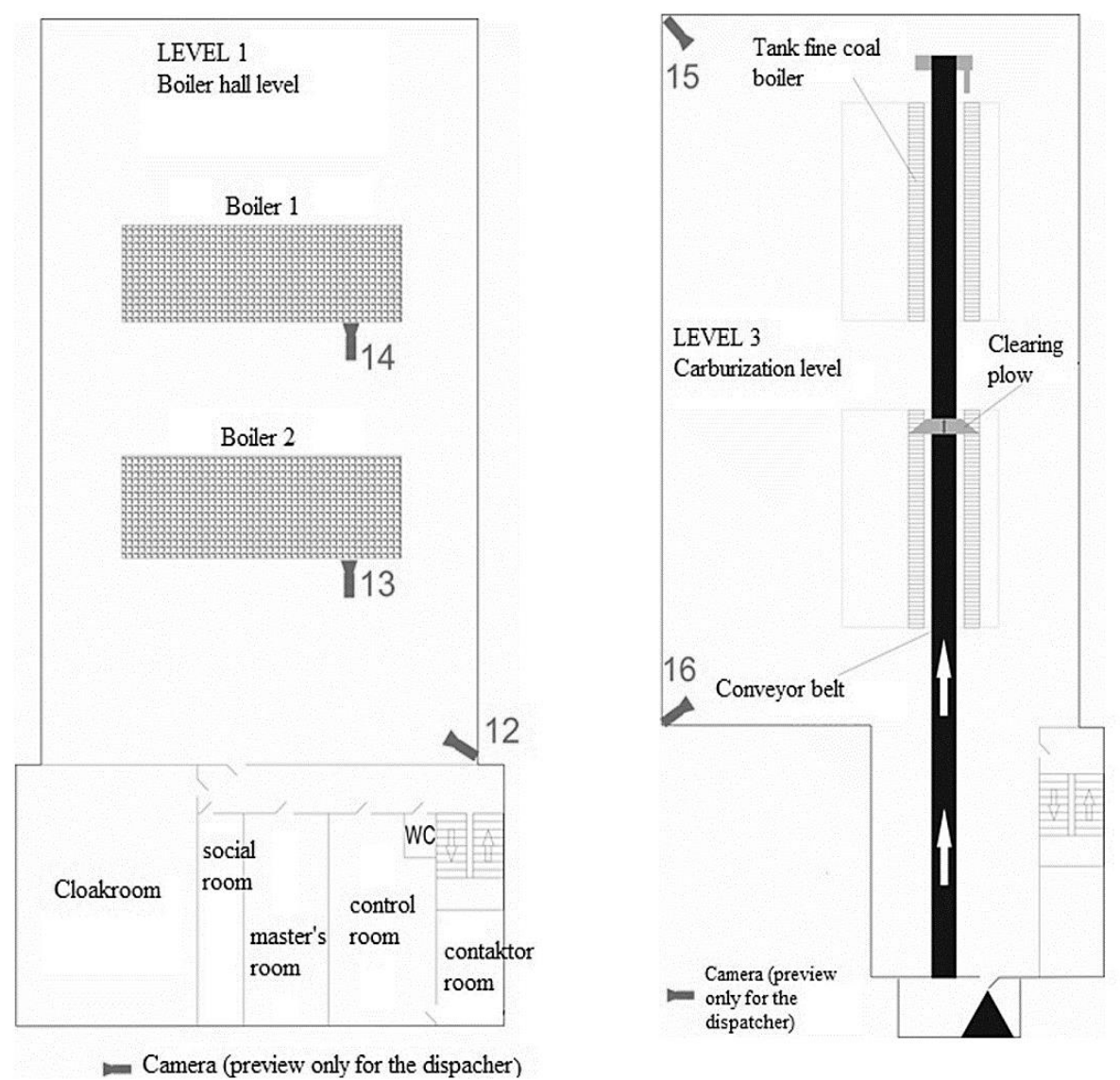

Fig. 2 Arrangement of vision system cameras for examples of boiler room levels:

Source: own study boiler room level (left) and carburizing level (right)

The main part of the boiler hall is monitored by camera no. 12, while camera no. 13 and 14 monitors the furnace of boilers 1 and 2. Previewing the image from this place is useful in terms of a quick response to the occurrence of failures such as water leaks from boilers, system leaks within the hearth or fire. In addition, the monitoring will allow to detect the presence of unauthorized 
persons in the boiler room and violations of health and safety rules. Camera no. 15 and 16, covering the carburizing level, provide remote observation of fine coal transport during carburizing. Supervision in this respect is necessary to ensure the correctness of: transporting the fine coal by means of a belt conveyor, operation of the material scraping device from the belt conveyor to the appropriate container and the material falling through the grates to the fine dust container.

Moreover, at the carburization level, there are separate zones exposed to the occurrence of an explosive mixture (Ex). At the level of carburization, open fire and smoking are strictly prohibited. As a result, the video monitoring system in this place performs the function of supervision over employees in terms of compliance with health and safety rules and the function of fire supervision.

\section{Selection of camera parameters}

The cameras used in video monitoring systems are characterized by different operating parameters, so each time the parameters should be selected for a specific monitored area. The choice of camera parameters is associated with two most important parameters: the size of the image sensor (sensor), which determines the size of the image produced, and the focal length of the lens as the distance between the image sensor and the central point of the lens' optical system.

Table 1 Determined operating parameters of individual cameras

\begin{tabular}{|c|c|c|c|c|c|c|}
\hline $\begin{array}{c}\text { Camera } \\
\text { no }\end{array}$ & $\begin{array}{l}\text { Supervised } \\
\text { area }\end{array}$ & $\begin{array}{l}\text { Distance } \\
\text { from the } \\
\text { object [m] }\end{array}$ & $\begin{array}{c}\text { Required } \\
\text { field of view } \\
\text { width [m] }\end{array}$ & $\begin{array}{c}\text { Sensor } \\
\text { size } \\
\text { [inch] }\end{array}$ & $\begin{array}{c}\text { Focal } \\
\text { length } \\
{[\mathrm{mm}]}\end{array}$ & $\begin{array}{c}\text { Viewing } \\
\text { angle, } \\
\text { horizontal }\left[{ }^{\circ}\right]\end{array}$ \\
\hline 1. & Main gate & 7.0 & 8.0 & $1 / 4$ & 3.0 & 59.1 \\
\hline 2. & Front of the scale & 6.0 & 3.0 & $1 / 4$ & 6.7 & 28.5 \\
\hline 3. & Back of the scale & 6.0 & 3.0 & $1 / 4$ & 6.7 & 28.5 \\
\hline 4. & $\begin{array}{l}\text { Main entrance } \\
\text { to the building }\end{array}$ & 6.0 & 5.0 & $1 / 4$ & 3.0 & 59.1 \\
\hline 5. & $\begin{array}{l}\text { Rear entrance } \\
\text { of the building }\end{array}$ & 6.0 & 5.0 & $1 / 4$ & 3.0 & 59.1 \\
\hline 6. & Coal storage site & 30.0 & 16.0 & $1 / 4$ & 6.4 & 29.8 \\
\hline 7. & $\begin{array}{l}\text { Heavy equipment } \\
\text { shelter }\end{array}$ & 20.0 & 7.0 & $1 / 4$ & 9.6 & 20.1 \\
\hline 8. & $\begin{array}{l}\text { Fuel distributor, } \\
\text { parking lot }\end{array}$ & 20.0 & 20.0 & $1 / 3$ & 4.8 & 53.1 \\
\hline 9. & Charging grate & 6.0 & 6.0 & $1 / 3$ & 4.8 & 53.1 \\
\hline 10. & Slag conveyor & 9.0 & 5.0 & $1 / 3$ & 8.6 & 31.2 \\
\hline 11. & Workshop & 6.0 & 4.0 & $1 / 4$ & 5.1 & 36.9 \\
\hline 12. & Boiler Hall & 11.0 & 7.0 & $1 / 4$ & 5.3 & 35.6 \\
\hline 13. & Boiler furnace 1 & 2.5 & 3.0 & $1 / 3$ & 4.0 & 61.9 \\
\hline 14. & Boiler furnace 2 & 2.5 & 3.0 & $1 / 3$ & 4.0 & 61.9 \\
\hline 15. & Carburization level & 13.0 & 7.0 & $1 / 4$ & 6.3 & 30.2 \\
\hline 16. & Carburization level & 13.0 & 7.0 & $1 / 4$ & 6.3 & 30.2 \\
\hline
\end{tabular}

Source: own study

The remaining camera parameters will be of secondary importance. These two parameters affect the size of the area that will be visible on the screen of the 
video monitoring operator. The parameters of the cameras ensuring the optimal transfer of the observed area to the system monitors in the analyzed enterprise were determined using the Dravis "Focus" program and are presented in Table 1.

The choice of camera models for the planned video monitoring system should always be preceded by an analysis of the basic parameters of the cameras according to the expected area of observation of the area. Another important issue is the selection of appropriate camera housings, taking into account the weather conditions (for external cameras) and the working environment conditions (for internal cameras).

\section{CONCLUSIONS}

The concept of the video monitoring system in the examined industrial facility should be built in accordance with the principle of creating alarm systems. In the first stage, it is necessary to analyze the existing risks and nuisance of work and identify all the sensitive places in the area of the surveyed company. Next, projections of the area and buildings covered by the concept of introducing monitoring should be analyzed.

After identifying the dangerous places in the enterprise, it is necessary to define the desired functions to be fulfilled by the video surveillance. After determining the number of cameras and their location, the basic parameters of the optical system of the cameras should be determined, which will allow to choose the model and type of the camera. The detailed settings of the camera operation parameters were made with the use of computer software supporting the design of video monitoring systems.

The adopted concept of video monitoring for the industrial plant under study is a comprehensive safety engineering tool for building a higher level of safety in the heat production process and people's safety at work. The proposed video monitoring can be used to monitor the technological process in the examined enterprise at a distance. In addition, the analysis of threats and nuisances in the work process allowed to optimize the course of some works with the use of the video monitoring system for the heating plant.

As a result of the implementation of the IP video monitoring system, in the municipal thermal power plant, the company could achieve the following goals:

- the possibility of verifying the fire hazard of the coal storage yard and the process carburizing line,

- supervision over the refueling process in the explosion hazard zone,

- $\quad$ supervision of critical parts of the technological process, such as: fire, leaks in boilers and water leaks, leaks in the gas installation within the furnace,

- improvement of the work process in the area of the entrance gate (control of weighed vehicles and the process of weighing deliveries without leaving the workplace), 
- improving the safety of employees and efficient monitoring of their compliance with health and safety regulations,

- protection against intrusion into the premises of unauthorized persons,

- supervision of the heavy machinery park,

- protection of coal and other equipment against theft.

The implementation of the video monitoring system increased the level of safety of employees and property in the heating plant. The system enabled employees to remotely supervise the technological process of heat generation, which limited the number of employees involved in the control process. The use of video monitoring allowed for a quick response to emergencies and threats to the safety of machines and people in the technological process. On the other hand, the use of more advanced video monitoring techniques may bring further benefits in the supervision of industrial processes, as described by the authors of the publication (Tsakanikas and Dagiuklas, 2018, Kardas and Ccekli, 2017, Deligiannidis and Arabnia, 2015).

\section{ACKNOWLEDGMENTS}

The article was written in support of BK-273/ROZ3/2021 (13/030/BK_21/0065) research under the title "Department of Production Engineering' resources development for carrying out activities in the areas related to the Silesian University of Technology Priority Research Areas".

\section{REFERENCES}

Deligiannidis, L., Arabnia, H. R. (2015). Chapter 8: Security surveillance applications utilizing parallel video-processing techniques in the spatial domain. In: Emerging Trends in Image Processing, Computer Vision and Pattern Recognition, pp. 117130.

Donald, F., Donald, C., Thatcher, A. (2015). Work exposure and vigilance decrements in closed circuit television surveillance. Applied Ergonomics, vol. 47, pp. 220-228, DOI: 10.1016/j.apergo.2014.10.001.

Elharrouss, O., Almaadeed, N., Al-Maadeed, S. (2021). A review of video surveillance systems. Journal of Visual Communication and Image Representation, vol. 77, DOI: 10.1016/j.jvcir.2021.103116.

Gembalska-Kwiecień, A. (2018). Advancement of tools supporting improvement of work safety in selected industrial company. Menagement Systems in Production Engineering, vol. 26, issue 1, pp. 31-34, DOI: 10.2478/mspe-2018-0005.

Ignac-Nowicka, J. (2018a) Inżynieria bezpieczeństwa. Wybrane zagadnienia, Gliwice: Wydawnictwo Pol. Śl.

Ignac-Nowicka, J. (2016). Rozwój techniki sensorowej jako inteligentna specjalizacja w inżynierii bezpieczeństwa. Systemy Wspomagania w Inżynierii Produkcji. Metody i narzędzia inżynierii produkcji dla rozwoju inteligentnych specjalizacji, vol. 4, pp. 32-42.

Ignac-Nowicka, J. (2018b). Application of the FTA and ETA method for gas hazard identification for the performance of safety systems in the industrial department. Menagement Systems in Production Engineering, vol. 26, issue 1, pp. 23-26, DOI: $10.2478 / \mathrm{mspe}-2018-0003$.

Kałużny, P. (2008). Telewizyjne systemy dozorowe, 1st ed. Warszawa: WKit.

Kardas, K., Cicekli, N. K. (2017). SVAS: Surveillance Video Analysis System. Expert Systems With Applications, vol. 89, DOI: 10.1016/j.eswa.2017.07.051. 
Kister, Ł. (2010). Prawne aspekty dopuszczalności monitoringu wizyjnego - ochrona wizerunku osoby. Ochrona Mienia i Informacji, nr 6.

Konsek-Ciechońska, J. (2017). Operational and strategic controlling tools in microenterprises - case study. Management Systems in Production Engineering, vol. 25, issue 4, pp. 278-282, DOI: 10.1515/mspe-2017-0041.

Lim, M. ., Tang, S., Chan, C.S. (2014). Surveillance: Intelligent framework for multiple events detection in surveillance videos. Expert Systems with Applications, vol. 41, pp. 4704-4715, DOI: 10.1016/j.eswa.2014.02.003.

Nguyena, M.., Truongb, L.H., Tranb, T.T., Chienb, C. (2020). Artificial intelligence based data processing algorithm for video surveillance to empower industry 3.5. Computers \& Industrial Engineering, vol. 148, DOI: 10.1016/j.cie.2020.106671.

Ordysińska, M. (2006). Aspekty prawne funkcjonowania systemów monitoringu wizyjnego w Polsce. Cz. I. Systemy Alarmowe, nr 4.

Pihowicz, W. (2005). Wybrane zagadnienia inżynierii bezpieczeństwa technicznego procedura wykrywania miejsc niebezpiecznych w podzespołach krytycznych obiektów technicznych. Wrocław: Wydawnictwo OWPW.

Pihowicz, W. (2008). Inżynieria bezpieczeństwa technicznego. Problematyka podstawowa. Warszawa: WNT.

PN-EN 62676-4 (2015). Systemy dozorowe CCTV stosowane w zabezpieczeniach Cz.4: Wytyczne stosowania., Warszawa: PKN.

Tsakanikas, V., Dagiuklas, T. (2018). Video surveillance systems-current status and future trends. Computers and Electrical Engineering, vol. 70, DOI: 10.1016/j.compeleceng.2017.11.011.

Wójcik, A. (2004). Mechaniczne i elektroniczne systemy zabezpieczeń. Literatura fachowa dla firm i instytucji. Warszawa: Wydawnictwo Verlag Dashofer.

Żabicki, D. (2013). Ochrona peryferyjna obiektów przemysłowych. Ochrona Mienia i Informacji, nr 1.

\begin{abstract}
The article presents the use of video monitoring in a production company on the example of municipal thermal power plant. After analyzing the hazards and work inconvenience occurring in the analyzed enterprise, video surveillance zones have been designated with the division into the indoor and outdoor monitoring system. Video surveillance is provided for production, auxiliary and delivery processes. Moreover, video monitoring performs a control function over the occupation health in workstations at risk of explosion or fire. In addition, observation points have been set up in the visual monitoring system, among which the internal ones are served by the dispatcher responsible for the production process, while the external are operated by security guards of the facility.
\end{abstract}

Keywords: video monitoring, supervision of the production process, video surveillance zones 